\title{
MENCEGAH TERJADINYA PERNIKAHAN SEDARAH DENGAN MEMAHAMI PARTUTURON DALAM MASYARAKAT BATAK ANGKOLA-MANDAILING
}

\author{
Husniah Ramadhani Pulungan \\ Lecturer of Muhammadiyah South Tapanuli University Padangsidimpuan \\ Jl. Sutan Muhammad Arief No. 32, Padangsidimpuan, Sumatera Utara \\ E-mail: husniah.umts@gmail.com
}

\begin{abstract}
Islam always take care about the way how to talk with the other people. This thing such as how we call our family or how we call someone else with the good name. We have to know well about it that prevent occurence incestuose marriage. In the speech community Batak Angkola - Mandailing have partuturon. It is like how we call all of our big family with polite name and this is very serious because in this society have the high appreciation of it. This time, many young people don't undestand about it. The writer hope this thing can help them to know more about partuturon. Partuturon is not just about the appreciation but it is about good personality when talk with the other people.
\end{abstract}

Key Words: Marriage Tribe, Partuturan, Batak, Angkola, Mandailing

\begin{abstract}
Abstrak
Islam senantiasa menjaga diri tentang cara untuk berbicara dengan orang lain. Perkara ini seperti bagaimana kita memanggil keluarga atau bagaimana kita memanggil orang lain dengan nama yang baik. Kita harus selalu tahu tentang hal tersebut untuk menjaga pernikahan sedarah. Dalam komunitas bahasa Batak Angkola - Mandailing memiliki partuturon. Ini adalah seperti bagaimana memanggil semua keluarga besar dengan nama sopan dan hal ini sangat serius karena dalam masyarakat ini memiliki apresiasi yang tinggi dari itu. Kali ini, banyak anak muda tidak mengerti tentang hal itu. Penulis berharap hal ini dapat membantu mereka untuk tahu lebih banyak tentang partuturon. Partuturon bukan hanya tentang apresiasi tapi ini adalah tentang kepribadian yang baik ketika berbicara dengan orang lain.
\end{abstract}

Kata Kunci: Pernikahan Sedarah, Partuturon, Batak, Angkola, Mandailing

\section{PENDAHULUAN}

Pernikahan sangat erat hubungannya dengan fitrah manusia karena sesungguhnya semua yang ada di alam semesta ini diciptakan Allah swt. Secara berapsang-pasangan. Fitrah inilah yang mendorong setiap makhluk Allah swt. Untuk berusaha menemukan pasangan hidupnya. Allah swt. Berfirman dalam Q.S. Yaasiin: 36 yang berbunyi: 


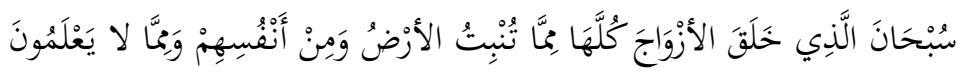

Artinya: "Maha Suci (Allah) yang telah menciptakan semuanya berpasang-pasangan, baik dari apa yang ditumbuhkan oleh bumi dan dari diri mereka sendiri, maupun dari apa yang tidak mereka ketahui."

Selanjutnya, dengan menikah, seseorang akan merasakan ketentraman dan kebahagiaan karena dapat meluapkan segala cinta dan perasaannya selama ini pada pasangan hidupnya di jalan yang sesuai dengan syariat Allah swt. Allah juga berfirman dalam Q.S. Ar-Ruum: 21 yang berbunyi:

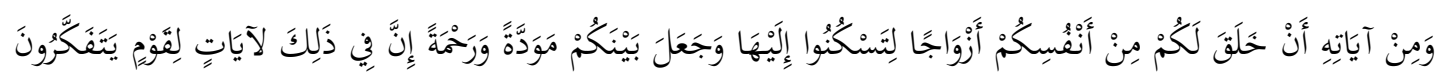

Artinya : "Dan di antara ayat-ayat-Nya ialah Dia menciptakan untukmu istri-istri dari jenismu sendiri, supaya kamu merasa nyaman kepadanya, dan dijadikan-Nya di antaramu mawadah dan rahmah. Sesungguhnya pada yang demikian itu benarbenar terdapat tanda-tanda bagi kaum yang berpikir".

Dengan demikian, jalan terbaik bagi dua insan berlainan jenis yang saling mencintai adalah menikah. Allah swt. telah berjanji akan selalu menyertai orang-orang yang menikah karena ingin menjauhkan diri dari maksiat. Dalam suatu hadis, Rasulullah saw. bersabda yang artinya: "Tiga golongan yang berhak ditolong oleh Allah swt., yaitu pejuang di jalan Allah, budak yang menebus dirinya dari tuannya, dan orang-orang yang menikah karena ingin menjauhkan diri dari yang haram". (H.R. Tirmidzi dari Abu Hurairah r.a.) ${ }^{1}$

Kemudian, salah satu syarat pernikahan adalah terbebasnya suami-istri dari penghalang-penghalang nikah. Keduanya atau salah satunya tidak terdapat penghalang tersebut baik hubungan nasab atau sebab-sebab tertentu, seperti sepersusuan, perbedaan agama, dan lain-lain. ${ }^{2}$

Berdasarkan pernyataan-pernyataan sebelumnya, maka penulis akan memaparkan bagaimana partuturon dalam masyarakat Batak Angkola-Mandailing agar terhindar dari pernikahan sedarah sesuai dengan salah satu syarat pernikahan yaitu tidak ada hubungan nasab. Berikut pemaparannya.

\section{MASYARAKAT TUTUR BATAK ANGKOLA-MANDAILING}

Masyarakat menurut kamus besar bahasa Indonesia adalah sejumlah manusia dalam arti seluas-luasnya dan terikat suatu kebudayaan yang mereka anggap sama. Masyarakat tidak akan pernah terlepas dari tutur atau dengan kata lain disebut dengan masyarakat tutur (speech community). Kalau suatu kelompok orang atau suatu masyarakat mempunyai verbal repertoir yang relatif sama serta mereka mempunyai penilaian yang sama terhadap norma-

\footnotetext{
1 Yustisianisa, Panduan Pranikah For Muslimah, (Yogyakarta: Citra Risalah, 2010), hlm. 26-28

2 Syaikh Muhammad bin Ibrahim bin Abdullah At-Tuwajiri, Ensiklopedi Islam Kaffah, (Surabaya: Pustaka Yassir, 2012), hlm. 910
} 
norma pemakaian bahasa yang digunakan dalam masyarakat itu, maka dapat dikatakan bahwa kelompok orang itu atau masyarakat itu adalah sebuah masyarakat tutur. ${ }^{3}$ Jadi, masyarakat tutur bukanlah hanya sekelompok orang yang menggunakan bahasa yang sama, melainkan kelompok orang yang mempunyai norma yang sama dalam menggunakan bentuk-bentuk bahasa.

Selanjutnya, dilihat dari sempit dan luas verbal repertoirnya, dapat dibedakan adanya dua macam masyarakat tutur, yaitu:

1. Masyarakat tutur yang repertoir masyarakatnya lebih luas, dan menunjukkan verbal repertoir setiap penutur lebih luas pula.

2. Masyarakat tutur yang sebagian anggotanya mempunyai pengalaman sehari-hari dan aspirasi hidup yang sama, dan menunjukkan pemilikan wilayah linguistik yang lebih sempit, termasuk juga perbedaan variasinya. ${ }^{4}$

Kedua jenis masyarakat tutur ini terdapat baik dalam masyarakat yang termasuk kecil dan tradisional maupun masyarakat besar dan modern.

Tulisan ini akan lebih fokus pada jenis masyarakat yang sebagian anggotanya mempunyai pengalaman sehari-hari dan aspirasi hidup yang sama, dan menunjukkan pemilikan wilayah linguistik yang lebih sempit, termasuk juga perbedaan variasinya. Di samping itu, masyarakat tuturnya juga termasuk kecil dan tradisional, dalam hal ini adalah masyarakat tutur Batak Angkola-Mandailing.

Masyarakat tutur Batak Angkola-Mandailing mengenal adanya partuturon yaitu merupakan istilah perkerabatan yang memiliki nilai-nilai luhur adab pergaulan orang per orang dan kelompok per kelompok dalam masyarakat. Pada akhir tahun 1960-an dan awal tahun 1970-an telah terjadi perubahan drastis dalam partuturon. Generasi muda sangat malas martarombo, sehingga kawula muda dengan mudah menerjemahkan kata oom dalam bahasa Belanda menjadi $u d a$. Padahal orang yang disapa $u d a$ itu barangkali adalah tulang 'saudara laki-laki ibu, dalam bahasa Indonesia disebut dengan paman dan dalam bahasa Jawa disebut dengan pakde', amang boru 'suami dari saudara perempuan ayah, dalam bahasa Indonesia disebut dengan bapak mertua atau mertua laki-laki', amang $u d a$ 'adik laki-laki ayah, dalam bahasa Indonesia disebut dengan paman dan dalam bahasa Jawa disebut dengan paklek', amang tua 'abang ayah, dalam bahasa Indonesia disebut dengan paman dan dalam bahasa Jawa disebut dengan pakde', apak ketek 'suami dari adik perempuan ibu, dalam bahasa Indonesia disebut dengan paman' atau apak tuo 'suami dari kakak perempuan Ibu, dalam bahasa Indonesia disebut dengan paman'. ${ }^{5}$

\footnotetext{
${ }^{3}$ Abdul Chaer dan Leonie Agustina. Sosiolinguistik Perkenalan Awal, (Jakarta: Penerbit PT Rineka Cipta, 2004), hlm. 36

${ }^{4}$ Ibid, hlm. 38

${ }^{5}$ Basyral Hamidi Harahap, Siala Sampagul, (Bandung: Pustaka, 2004)
} 
Keengganan martarombo ini telah berdampak pada menurunnya kesopansantunan, dan menurunkan kadar rasa malu. Oleh karena itu, partuturon yang banyak itu seharusnya kembali diajarkan kepada generasi muda, agar kelestarian nilai-nilai luhur budaya daerah ini dapat dijaga.

\section{PARTUTURON DALAM MASYARAKAT BATAK ANGKOLA-MANDAILING}

Partuturon merupakan suatu hal yang menarik karena partuturon yang berasal dari kata tutur ini merupakan istilah sapaan yang dipakai ketika menyapa orang lain dan kata kunci kekerabatan yang menentukan posisi setiap orang dalam jaringan kekerabatan Dalihan na Tolu. ${ }^{6}$

Dalihan na Tolu dikenal dengan kahanggi, anak boru dan mora yang merupakan simbol tiga kelompok masyarakat adat yang saling bekerjasama dalam menyelesaikan semua urusan. Segala beban dipikul bersama. Ini adalah simbol gotong-royong, kebersamaan, hak dan kewajiban, tenggang rasa, kasih sayang, holong, sehingga kekerabatan tetap terpelihara dengan baik.7

Selanjutnya, dalam masyarakat tutur Batak Angkola-Mandailing, pertemuan pertama pada umumnya diawali dengan dialog pertanyaan dan jawaban tentang nama marga masing-masing karena dengan saling mengetahui marga, maka orang yang baru berkenalan itu mengetahui tutur mereka yang tepat (kebiasaan ini disebut dengan martarombo). Kebiasaan martarombo berkembang dalam pergaulan sehari-hari dengan orang di luar masyarakat Batak Angkola-Mandailing. Hal ini dilakukan dengan mencari tokoh, tempat, kampung, organisasi atau lembaga yang dikenal dengan baik. Dengan demikian, perasaan kebersamaan akan tercipta. Hal ini merupakan bukti bahwa nilai tutur berperan penting dalam penyesuaian diri dengan lingkungan yang baru.

Menurut Hall, ada 6 karakteristik komunikasi yang bersifat etis, yaitu:

1. Autheticity: sekalipun orang tidak menyebutkan sesuatu apa pun tentang dirinya atau apa yang ada di dalam benaknya, komunikasinya haruslah murni, asli, dan mengizinkan orang lain mengetahui siapa mereka sesungguhnya.

2. Inclusion: pemahaman orang lain terhadap dunia harus diperlakukan sama pentingnya sebagai miliknya sendiri. Komunikator etika mengusahakan untuk memasukkan dan menghargai sudut pandang orang lain di dalam dialog.

3. Confirmation: mengenal orang lain secara aktif nilai dapat menegaskan keberadaan orang lain dan saling menguntungkan di dalam dialog. Melibatkan diri di dalam dialog adalah menceburkan diri pada suatu jenis komunikasi yang benar-benar menghargai orang lain.

4. Presentness: menentang godaan untuk tetap menjaga jarak dari orang lain atau dialihkan oleh kepentingan internal dan eksternal. Bahkan, pada saat ini orang lain dan dialog di antara orang-orang tersebut menjadi prioritas utama.

${ }^{6}$ Ibid, hlm. 89

${ }^{7}$ Ibid, hlm. 23 
5. Spirit of mutual equality: semangat kesetaraan. Gagasan ini berseberangan dengan seseorang yang menguasai orang lain atau mendominasi percakapan. Bahkan, kesadaran pada saling mengakui keabsahan memungkinkan seluruh kalangan yang terlibat untuk berbicara secara bebas dan terbuka.

6. Supportive climate: suasana yang mendukung penting untuk mendorong setiap orang untuk mengambil bagian dan menangguhkan penilaian tentang kedudukan seseorang sebagai orang yang memiliki hak untuk menilai orang lain. ${ }^{8}$

Berdasarkan cara-cara mengatasi tantangan komunikasi yang bersifat etis tersebut di atas ternyata telah dimiliki masyarakat tutur Batak Angkola-Mandailing juga. Kemacetan komunikasi etika itu dapat diatasi dengan implementasi nilai-nilai luhur budaya masyarakat. Partuturon atau istilah kekerabatan dalam masyarakat tutur Batak AngkolaMandailing terdiri atas 67 tutur. ${ }^{9}$ Hal ini dapat dilihat pada tabel 1. sebagai berikut.

Tabel 1.

Bentuk Bahasa Partuturon Masyarakat Tutur Batak Angkola-Mandailing

\begin{tabular}{|c|c|c|}
\hline No. & Partuturon & Bagan \\
\hline 1. & $\begin{array}{l}\text { Amang adalah tutur anak laki-laki dan } \\
\text { perempuan C dan D kepada ayah A. } \\
\text { Ayah A dan ibu B juga biasa menyapa } \\
\text { C dengan amang. Amang juga boleh } \\
\text { diucapkan kepada seorang tua laki-laki } \\
\text { pada saat perkenalan sebelum } \\
\text { martarombo . Misalnya, "Aha do marga ni } \\
\text { amang?" artinya "Apa marga bapak?" }\end{array}$ & $\begin{array}{cc}\mathrm{A} \\
\mathrm{Lk} \\
\mathrm{C} & \mathrm{B} \\
\mathrm{Ck} & \mathrm{D} \\
\text { C dan D menyapa amang kepada A }\end{array}$ \\
\hline 2. & $\begin{array}{l}\text { Amang boru adalah suami dari saudara } \\
\text { perempuan ayah kita (laki-laki dan } \\
\text { perempuan). Amang boru adalah juga } \\
\text { tutur perempuan yang sudah menikah } \\
\text { kepada ayah suaminya, mertua laki- } \\
\text { laki. Saudara laki-laki dari perempuan } \\
\text { yang sudah menikah itu pun juga } \\
\text { menyapa mertua laki-laki saudara } \\
\text { perempuannya itu dengan amang boru. }\end{array}$ & 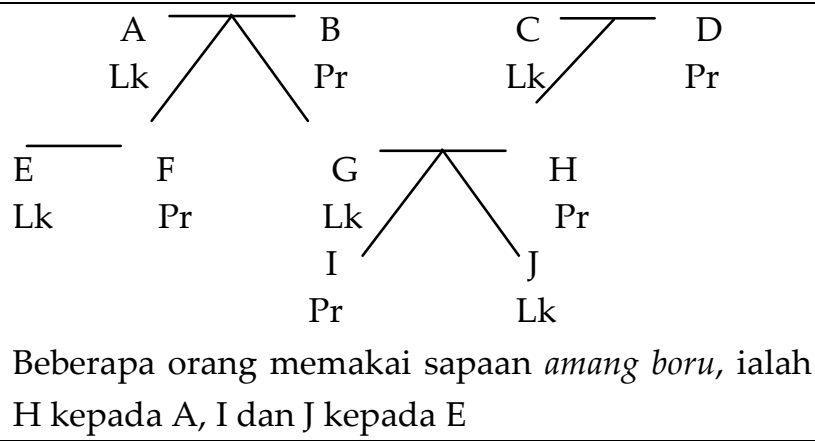 \\
\hline 3. & $\begin{array}{l}\text { Amang menek adalah tutur seorang ibu } \\
\text { kepada anak laki-laki dari anak } \\
\text { perempuan dari anak perempuannya. }\end{array}$ & 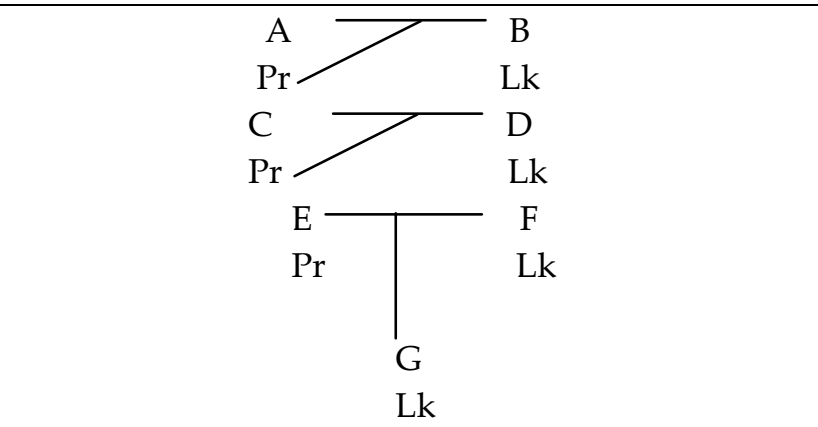 \\
\hline
\end{tabular}

${ }^{8}$ Ibid, h. $92-93$

${ }^{9}$ Ibid, h. 96-124 


\begin{tabular}{|c|c|c|}
\hline & & A menyapa amang menek kepada G \\
\hline 4. & $\begin{array}{l}\text { Amang mulak adalah ayah dari kakek } \\
\text { kita dari pihak ayah dengan perkataan } \\
\text { lain, ayah dari ayah dari ayah kita, atau } \\
\text { kakek dari ayah kita. }\end{array}$ & Jadi A adalah amang mulak bagi G dan $\mathrm{H}$ \\
\hline 5. & $\begin{array}{l}\text { Amang na poso adalah tutur perempuan } \\
\text { kepada anak laki-laki dari saudara laki- } \\
\text { lakinya. }\end{array}$ & 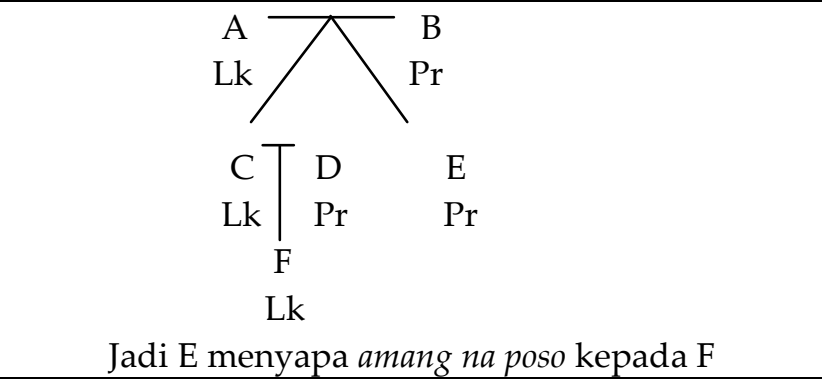 \\
\hline 6. & $\begin{array}{l}\text { Amang na poso mulak adalah sapaan } \\
\text { perempuan kepada cucu laki-laki dari } \\
\text { anak laki-laki amang na poso. }\end{array}$ & $\begin{array}{l}\text { E menyapa G dengan tutur kekerabatan amang na } \\
\text { poso karena kedudukan } \mathrm{G} \text { sama dengan cucu laki- } \\
\text { laki dari anak laki-laki G, yaitu K, maka E menyapa } \\
\text { K dengan sapaan amang na poso mulak. }\end{array}$ \\
\hline 7. & $\begin{array}{l}\text { Amang tobang adalah sapaan laki-laki } \\
\text { dan perempuan kepada suami dari } \\
\text { kakak ibu mereka. Sapaan ini juga } \\
\text { adalah sapaan kita kepada ayah dari } \\
\text { kakek kita. }\end{array}$ & $\begin{array}{l}\text { Pr } \\
\mathrm{Pr}\end{array}$ \\
\hline
\end{tabular}




\begin{tabular}{|c|c|c|}
\hline & & $\begin{array}{l}\text { sebabnya } \mathrm{K} \text { dan } \mathrm{L} \text { menyapa } \mathrm{B} \text { dengan sapaan } \\
\text { amang tobang. }\end{array}$ \\
\hline 8. & $\begin{array}{l}\text { Amang tua adalah sapaan kepada abang } \\
\text { ayah kita. }\end{array}$ & G dan H kepada C, abang dari E, ayah $\mathrm{G}$ dan $\mathrm{H}$. \\
\hline 9. & $\begin{array}{l}\text { Amang uda adalah tutur kepada adik } \\
\text { ayah kita. }\end{array}$ & Gdan H kepada E, adik laki-laki dari ayah mereka C \\
\hline 10. & Anak adalah sapaan bagi anak laki-laki. & $\begin{array}{c}\mathrm{C} \\
\mathrm{C}\end{array} \mathrm{D}_{\mathrm{D}}^{\mathrm{Br}}$ \\
\hline 11. & $\begin{array}{l}\text { Anak mulak adalah kebalikan amang } \\
\text { mulak. Jadi kita (laki-laki) adalah anak } \\
\text { mulak bagi ayah dari kakek kita dari } \\
\text { pihak ayah. }\end{array}$ & Gk \\
\hline 12. & $\begin{array}{l}\text { Anak tobang adalah kebalikan dari } \\
\text { amang tobang. }\end{array}$ & 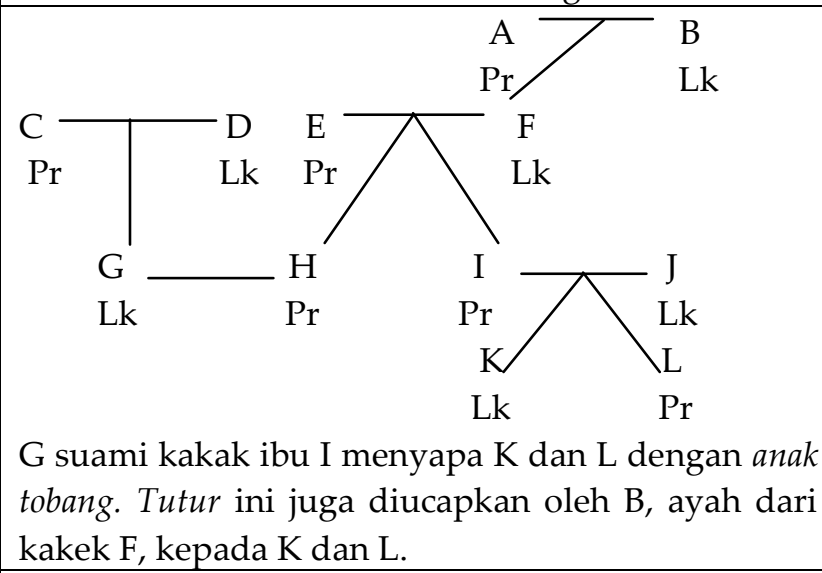 \\
\hline 13. & $\begin{array}{l}\text { Anggi adalah sapaan kepada saudara } \\
\text { yang lebih muda sesama laki-laki atau } \\
\text { sesama perempuan. Anggi, juga } \\
\text { merupakan sapaan kakek atau nenek } \\
\text { kepada cucunya. }\end{array}$ & 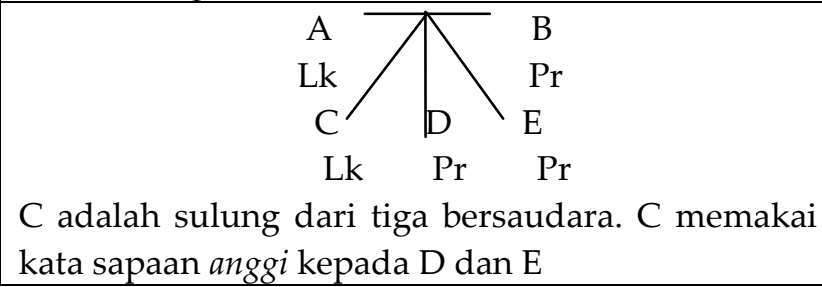 \\
\hline
\end{tabular}




\begin{tabular}{|c|c|c|}
\hline 14. & $\begin{array}{l}\text { Angkang adalah sapaan kepada saudara } \\
\text { yang lebih tua sesama laki-laki atau } \\
\text { sesama perempuan. Tutur ini juga } \\
\text { dipakai untuk menyapa istri angkang } \\
\text { kita. }\end{array}$ & 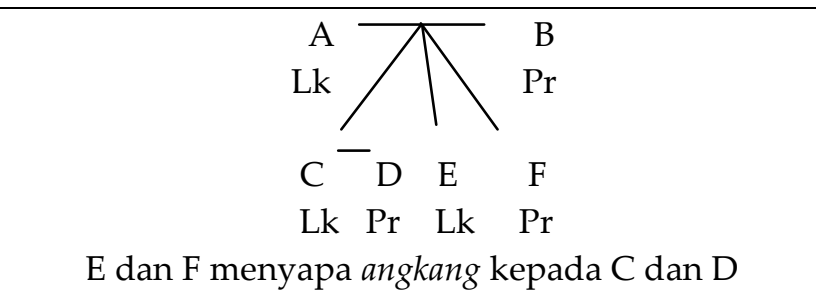 \\
\hline 15. & $\begin{array}{l}\text { Angkang mulak adalah kata sapaan kita } \\
\text { kepada anak perempuan dari kakek } \\
\text { ayah kita. }\end{array}$ & $\begin{array}{l}\text { Pk } \\
\text { Le }\end{array}$ \\
\hline 16. & $\begin{array}{l}\text { Apak ketek adalah suami dari adik } \\
\text { perempuan ibu kita. Tutur ini sama } \\
\text { artinya dengan amang menek. }\end{array}$ & 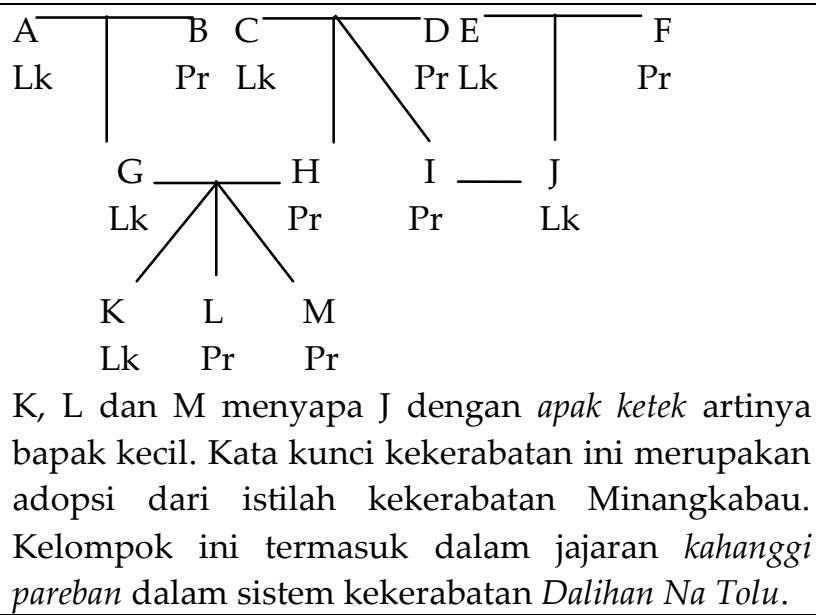 \\
\hline 17. & $\begin{array}{l}\text { Apak tuo adalah suami dari kakak ibu } \\
\text { kita. Tutur ini juga merupakan istilah } \\
\text { kekerabatan Minangkabau yang sering } \\
\text { ditrjemahkan menjadi apak tobang. Apak } \\
\text { tuo juga termasuk di dalam kelompok } \\
\text { kahanggi pareban dalam sistem } \\
\text { kekerabatan Dalihan Na Tolu. }\end{array}$ & 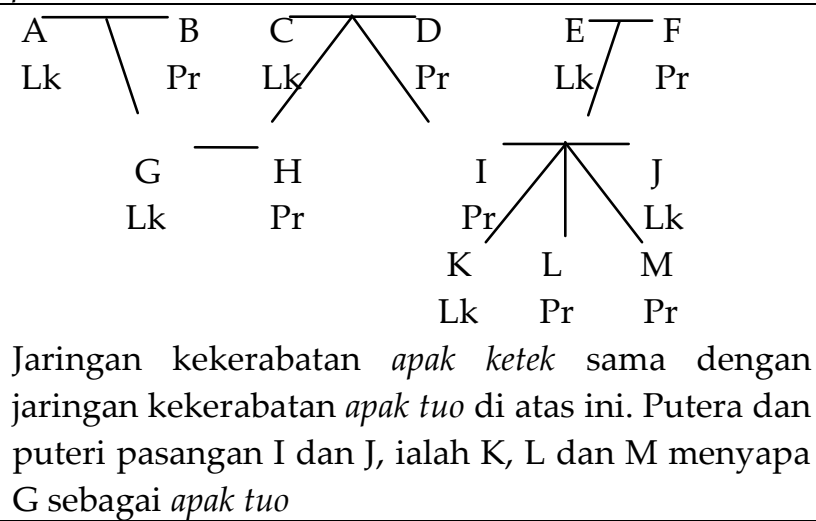 \\
\hline 18. & $\begin{array}{l}\text { Bayo ialah tutur timbal balik antara anak } \\
\text { boru laki-laki dan mora perempuan. }\end{array}$ & 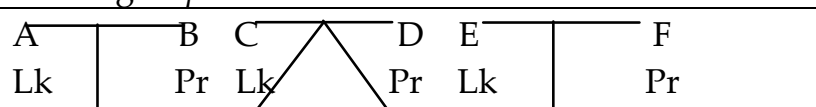 \\
\hline
\end{tabular}




\begin{tabular}{|c|c|c|}
\hline & & 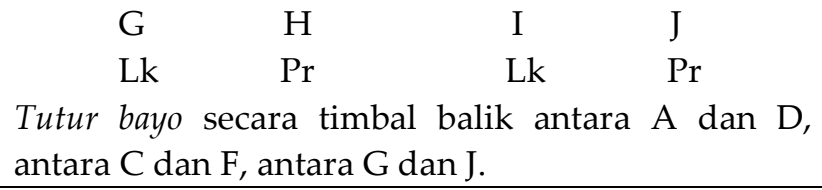 \\
\hline 19. & $\begin{array}{l}\text { Bere adalah sapaan seorang laki-laki } \\
\text { kepada anak laki-laki dan anak } \\
\text { perempuan } \\
\text { perempuannya. Tutur ini juga } \\
\text { diucapkan oleh mertua laki-laki dan } \\
\text { mertua perempuan kepada suami anak } \\
\text { perempuan mereka. }\end{array}$ & 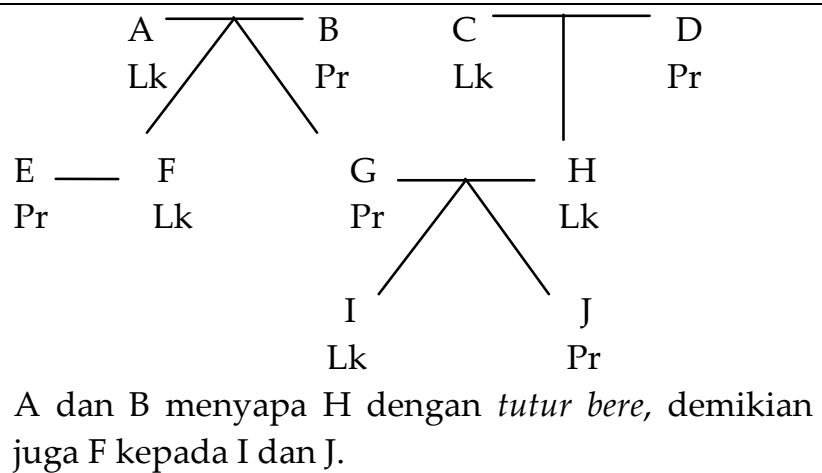 \\
\hline 20. & $\begin{array}{l}\text { Bere mulak adalah tutur laki-laki kepada } \\
\text { anak laki-laki dan anak perempuan dari } \\
\text { saudara perempuan kakeknya (ayah } \\
\text { dari ayahnya). Tutur ini juga diucapkan } \\
\text { oleh seorang ibu kepada amang boru } \\
\text { dari suaminya. }\end{array}$ & $\begin{array}{l}\text { E adalah saudara perempuan } \mathrm{C} \text {. C dan } \mathrm{D} \text { menyapa } \\
\text { bere kepada I dan } \mathrm{K} \text {. Kedudukan kakek dan cucu } \\
\text { laki-laki dari anak laki-laki adalah sama, maka } \\
\text { semua bere kakek adalah juga bere cucu laki-laki itu. } \\
\text { L menyapa bere kepada I dan K. Karena sapaan bere } \\
\text { yang diucapkan oleh } \mathrm{C} \text { kepada I dan } \mathrm{K} \text {, diulangi } \\
\text { lagi oleh L kepada I dan } \mathrm{K} \text {, maka tutur ini disebut } \\
\text { bere mulak. }\end{array}$ \\
\hline 21. & $\begin{array}{l}\text { Boru adalah istilah kekerabatan untuk } \\
\text { anak perempuan. }\end{array}$ & 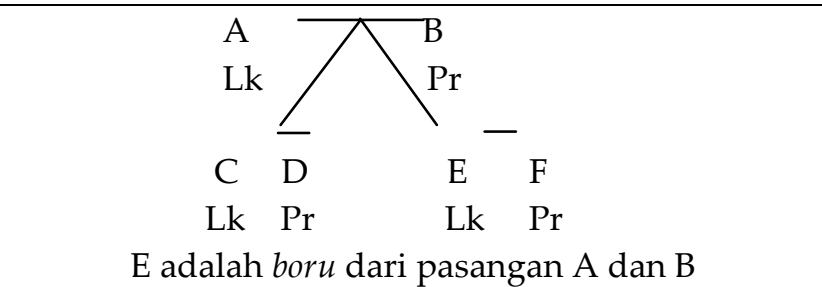 \\
\hline 22. & $\begin{array}{l}\text { Boru mulak, sapaan ini diucapkan oleh } \\
\text { seorang perempuan kepada anak } \\
\text { perempuan dari saudara perempuan } \\
\text { kakeknya (ayah dari ayahnya). }\end{array}$ & 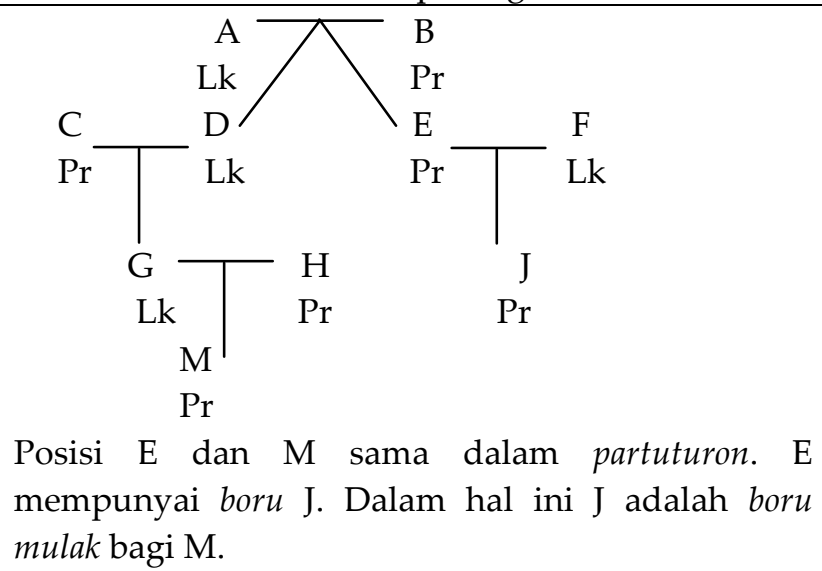 \\
\hline
\end{tabular}




\begin{tabular}{|c|c|c|}
\hline 23. & $\begin{array}{l}\text { Boru tulang, tutur ini diucapkan oleh } \\
\text { laki-laki dan perempuan kepada anak } \\
\text { perempuan dari saudara laki-laki ibu } \\
\text { mereka. }\end{array}$ & 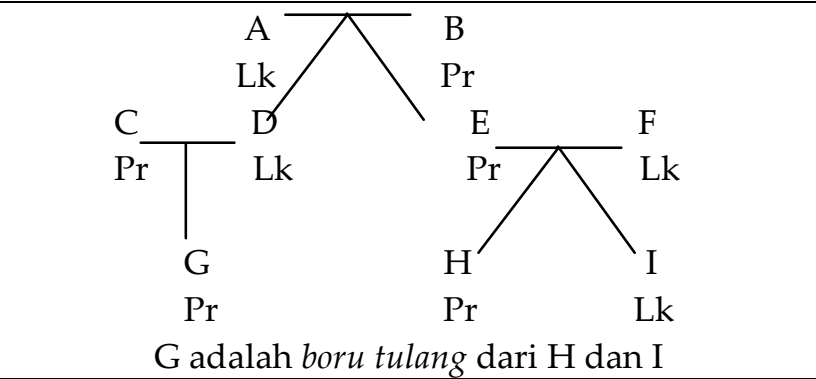 \\
\hline 24. & $\begin{array}{l}\text { Boru tulang halalango adalah tutur } \\
\text { seorang laki-laki kepada anak } \\
\text { perempuan dari anak laki-laki dari } \\
\text { saudara laki-laki ibu dari ibunya. }\end{array}$ & $\begin{array}{l}\text { Ke } \\
\text { K adalah boru tulang halalango bagi L di satu pihak } \\
\text { K adalah iboto bagi L, di lain pihak } \mathrm{K} \text { adalah boru } \\
\text { tulang bagi L. Walaupun tidak dilarang, namun } \\
\text { perkawinan antara K dan L tidak dianjurkan. }\end{array}$ \\
\hline 25. & $\begin{array}{l}\text { Bou adalah sapaan kepada saudara } \\
\text { perempuan ayah. Ini juga merupakan } \\
\text { sapaan seorang ibu kepada ibunda } \\
\text { suaminya. Istilah kekerabatan ini } \\
\text { merupakan bentuk singkat dari inang } \\
\text { boru dan namboru. Artinya, tokoh ini } \\
\text { sesungguhnya adalah inang karena ia } \\
\text { adalah saudara perempuan ayah, tetapi } \\
\text { juga sebagai boru karena ia adalah anak } \\
\text { perempuan kakek (ayah dari ayah). }\end{array}$ & $\begin{array}{cccc}\mathrm{C} & \mathrm{D} & \mathrm{Lk} \\
\mathrm{Lk} & \mathrm{Pr} & \mathrm{H} \\
& & \mathrm{Pk} & \mathrm{Pr} \\
\text { Sapaan G dan H kepada D ialah bou atau namboru. } \\
\text { Sapaan yang sama berlaku bagi F kepada B. }\end{array}$ \\
\hline 26. & $\begin{array}{l}\text { Bou mulak ialah sapaan laki-laki kepada } \\
\text { cucu perempuan dari anak laki-laki dari } \\
\text { saudara perempuan ayah kakek kita } \\
\text { dari pihak ayah. }\end{array}$ & $\begin{array}{c}\mathrm{A} \\
\mathrm{Lk} / \mathrm{D}_{\mathrm{Pr}} \\
\mathrm{Pr} \\
\mathrm{Ek}\end{array}$ \\
\hline & & 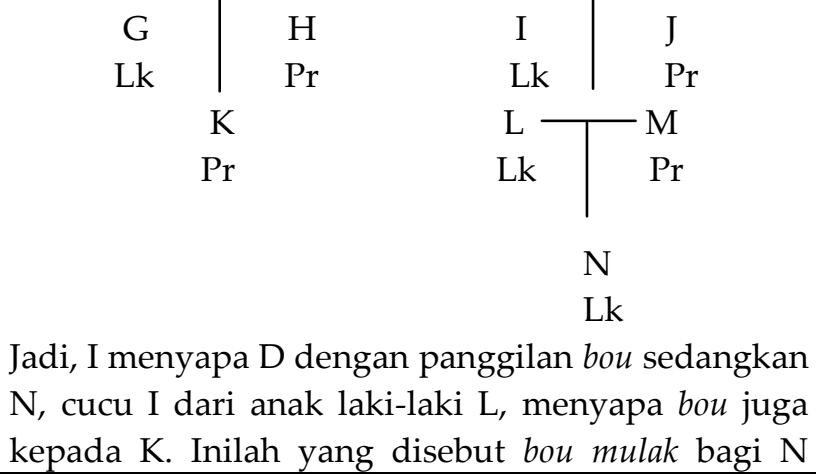 \\
\hline
\end{tabular}




\begin{tabular}{|c|c|c|}
\hline & & $\begin{array}{l}\text { karena sapaan kekerabatan itu berulang kembali } \\
\text { (mulak) pada generasi cucu-cucu mereka (D dan I) } \\
\text { dari anak laki-laki mereka ( } G \text { dan } L \text { ). }\end{array}$ \\
\hline 27. & Bujing adalah adik perempuan ibu. & $\mathrm{Li}_{\mathrm{Lk}}$ \\
\hline 28. & $\begin{array}{l}\text { Eda adalah tutur timbal balik antara } \\
\text { istri dan saudara perempuan suaminya. }\end{array}$ & $\begin{array}{llll} & \mathrm{D} \\
\text { D dan E saling menyapa secara timbal balik dengan } & \mathrm{Pr} & \mathrm{Pr} \\
\text { sapaan } e d a\end{array}$ \\
\hline 29. & $\begin{array}{l}\text { Etek sama dengan bujing. Tutur ini } \\
\text { merupakan pengaruh dari kekerabatan } \\
\text { Minangkabau pada tutur kekerabatan } \\
\text { Angkola-Mandailing. }\end{array}$ & 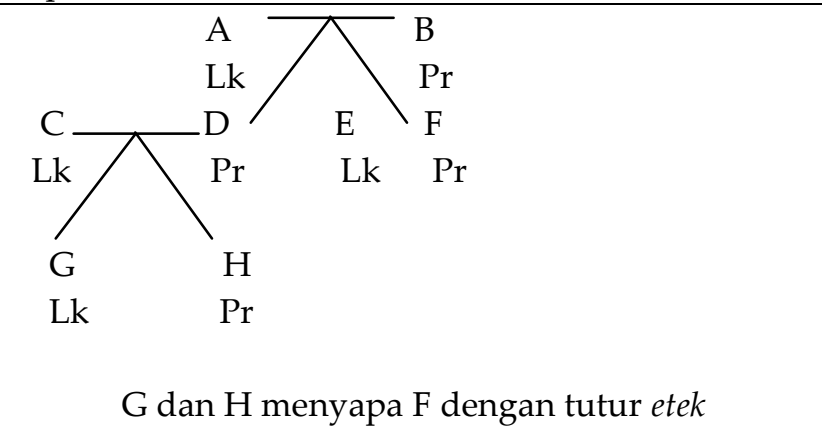 \\
\hline 30. & $\begin{array}{l}\text { Hela adalah sapaan mertua laki-laki } \\
\text { kepada suami anak perempuannya. } \\
\text { Bandingkan dengan bere. }\end{array}$ & 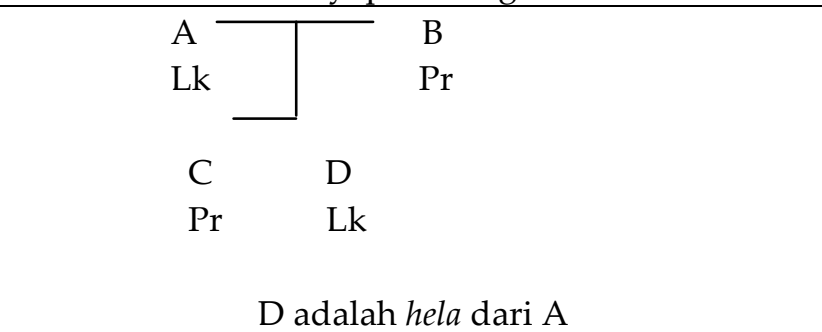 \\
\hline 31. & $\begin{array}{l}\text { Iboto adalah tutur timbal balik antara } \\
\text { saudara laki-laki dan saudara } \\
\text { perempuan. }\end{array}$ & $\begin{array}{cl} & \mathrm{A} \\
\mathrm{Ck} & \mathrm{Pr} \\
\mathrm{Ck} & \mathrm{Pr} \\
\mathrm{Pr} \\
\text { Dua bersaudara, laki-laki dan perempuan, C dan D } \\
\text { saling menyapa ito. }\end{array}$ \\
\hline 33. & $\begin{array}{l}\text { Iboto pamere adalah tutur timbal balik } \\
\text { antara saudara sepupu kandung, yaitu } \\
\text { anak laki-laki dan anak perempuan dari } \\
\text { dua atau lebih ibu yang bersaudara } \\
\text { kandung. }\end{array}$ & 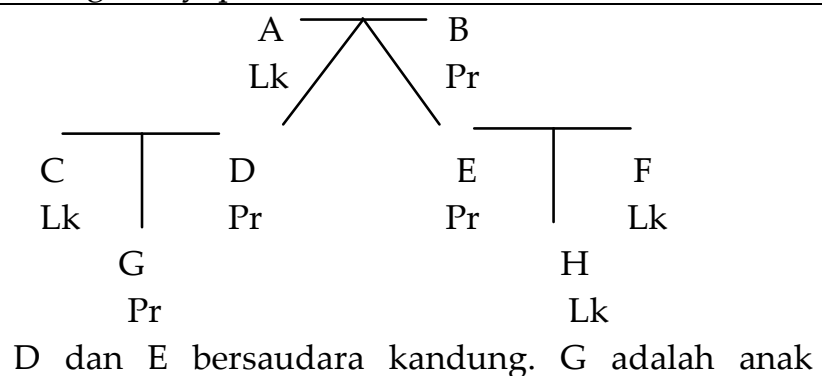 \\
\hline
\end{tabular}




\begin{tabular}{|c|c|c|}
\hline & & $\begin{array}{l}\text { perempuan } \mathrm{D} \text { dan } \mathrm{H} \text { anak laki-laki E. Secara timbal } \\
\text { balik } \mathrm{G} \text { dan } \mathrm{H} \text { adalah iboto pamere. }\end{array}$ \\
\hline 34. & $\begin{array}{l}\text { Inang adalah tutur anak laki-laki kepada } \\
\text { ibunya dan tutur timbal balik antara ibu } \\
\text { dan anak perempuannya. Tutur ini juga } \\
\text { diucapkan secara timbal balik antara } \\
\text { seorang istri dan saudara perempuan } \\
\text { dari ayah suaminya. }\end{array}$ & 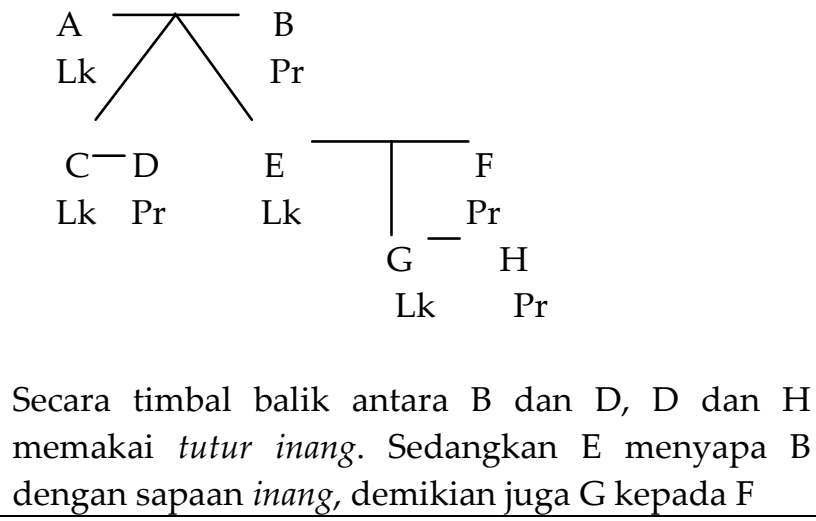 \\
\hline 35. & Inang boru, lihat bou. & - \\
\hline 36. & Inang boru mulak, lihat bou mulak. & - \\
\hline 37. & $\begin{array}{l}\text { Inang bujing, lihat bujing, nambujing dan } \\
\text { etek. }\end{array}$ & - \\
\hline 38. & $\begin{array}{l}\text { Inang mulak adalah tutur amang boru } \\
\text { kepada menantu perempuan dan tutur } \\
\text { timbal balik antara namboru suami dan } \\
\text { istrinya. Lihat juga inang. }\end{array}$ & 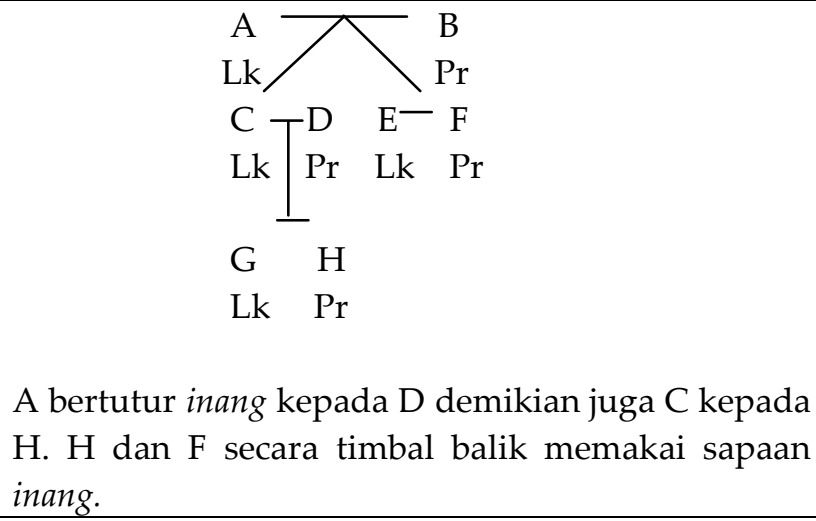 \\
\hline 39. & $\begin{array}{l}\text { Inang tobang sering disingkat menjadi } \\
\text { tobang adalah sapaan anak laki-laki dan } \\
\text { perempuan kepada kakak perempuan } \\
\text { ibu mereka. Sapaan yang sama kepada } \\
\text { nenek ibu mereka (ibu dari ibu dari } \\
\text { ibu). }\end{array}$ & Inang tobang atau tobang adalah sapaan $\mathrm{G}$ dan $\mathrm{H}$ \\
\hline 40. & $\begin{array}{l}\text { Inang tua adalah tutur kepada istri } \\
\text { amang tua, biasa juga disingkat menjadi } \\
\text { nantua. }\end{array}$ & G dan H menyapa D dengan istilah kekerabatan \\
\hline
\end{tabular}




\begin{tabular}{|c|c|c|}
\hline 42. & $\begin{array}{l}\text { Inang tulang mulak biasa disingkat } \\
\text { menjadi nantulang mulak, ialah tutur } \\
\text { dari amang boru suami kepada istri } \\
\text { suami tersebut, atau tutur kita (laki-laki } \\
\text { dan perempuan) kepada istri dari cucu } \\
\text { laki-laki dari saudara laki-laki ibu kita. }\end{array}$ & $\begin{array}{l}\text { Sapaan nantulang mulak oleh F kepada H, oleh I, J, K } \\
\text { dan L kepada } \mathrm{N} \text {, oleh } \mathrm{P} \text { kepada } \mathrm{R}\end{array}$ \\
\hline 43. & $\begin{array}{l}\text { Inang } u d a \text { biasa disingkat menjadi } \\
\text { nanguda, ialah tutur kepada istri dari } \\
\text { adik laki-laki ayah. }\end{array}$ & 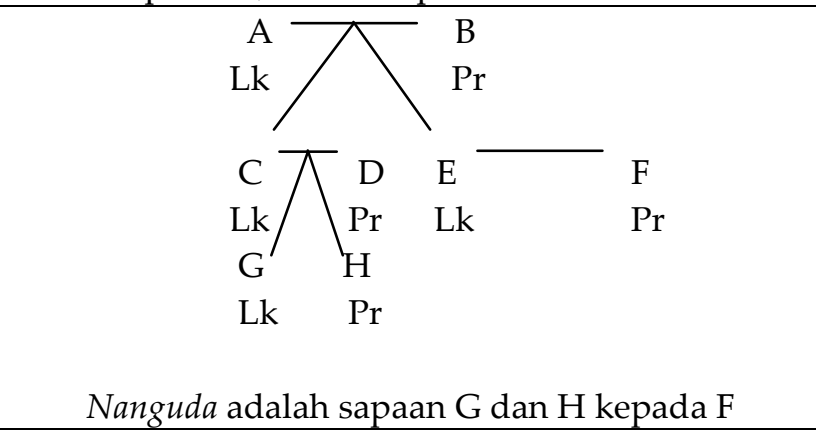 \\
\hline 44. & $\begin{array}{l}\text { Ipar adalah tutur laki-laki kepada } \\
\text { saudara laki-laki istrinya. Lihat juga } \\
\text { tunggane. }\end{array}$ & 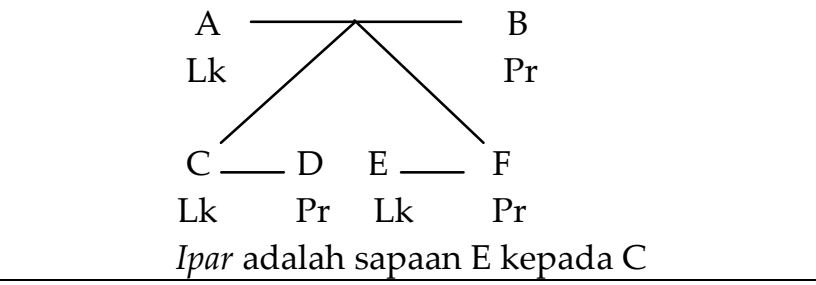 \\
\hline 45. & Kahanggi adalah kerabat semarga. & - \\
\hline 46. & $\begin{array}{l}\text { Lae adalah tutur laki-laki kepada suami } \\
\text { dari saudara perempuannya, kebalikan } \\
\text { dari saudara ipar. }\end{array}$ & Lae adalah sapaan $\mathrm{C}_{\mathrm{Pr}}^{\mathrm{A}}$ \\
\hline 47. & $\begin{array}{l}\text { Mora adalah seluruh kandung laki-laki } \\
\text { kerabat istri yaitu saudara laki-laki, } \\
\text { ayah, paman dan kakeknya atau } \\
\text { kerabat semarga dari istri. Mora adalah } \\
\text { satu di antara tiga unsur Dalihan } \mathrm{Na} \\
\text { Tolu. }\end{array}$ & 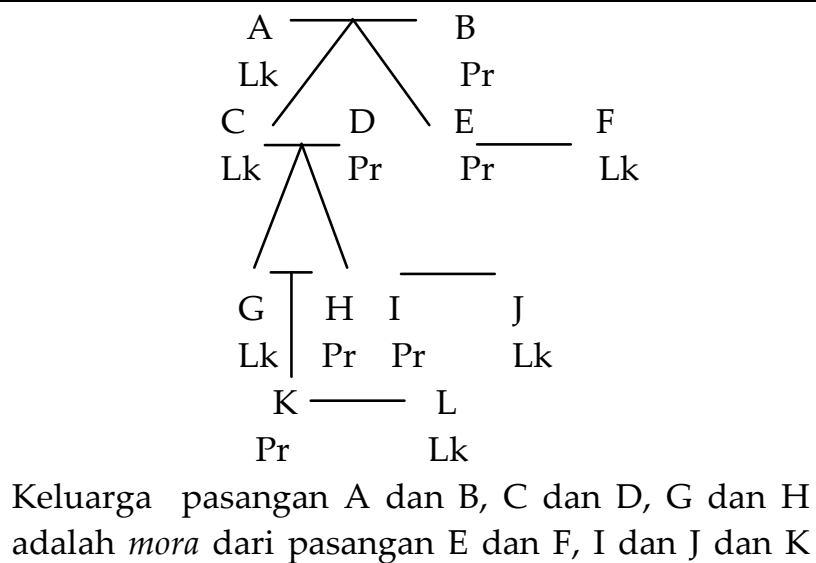 \\
\hline
\end{tabular}




\begin{tabular}{|c|c|c|}
\hline & & $\begin{array}{l}\text { dan L. A, C dan G adalah saudara kandung para } \\
\text { istri F, J dan L. }\end{array}$ \\
\hline 49. & Namboru mulak, lihat bou mulak. & - \\
\hline 50. & $\begin{array}{l}\text { Nanguda adalah istri dari adik laki-laki } \\
\text { ayah. }\end{array}$ & $\begin{array}{ccc}\mathrm{A} \\
\mathrm{Lk}\end{array} \varlimsup_{\mathrm{G}}^{\mathrm{B}} \mathrm{Pr}$ \\
\hline 51. & $\begin{array}{l}\text { Nantulang adalah sapaan kepada istri } \\
\text { saudara laki-laki ibu. }\end{array}$ & 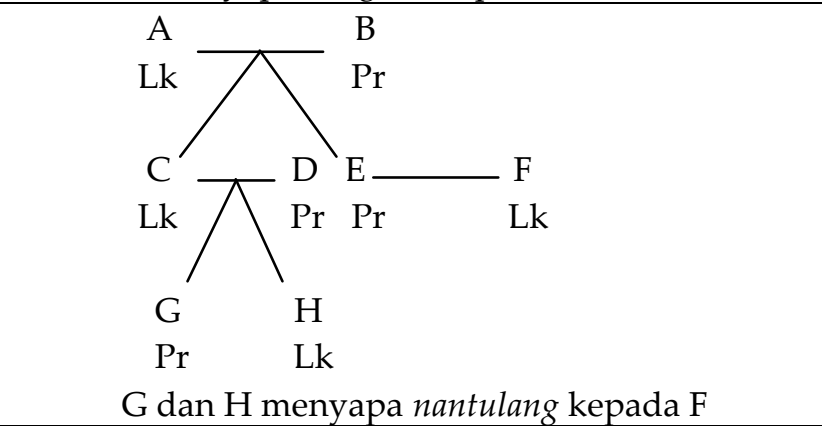 \\
\hline 52. & $\begin{array}{l}\text { Nantulang mulak adalah sapaan amang } \\
\text { boru kepada istri dari amang na poso. }\end{array}$ & $\begin{array}{c}\mathrm{C} \\
\mathrm{Lk} \\
\mathrm{Ck}\end{array}$ \\
\hline 53. & $\begin{array}{l}\text { Ompung adalah kakek dan nenek yaitu } \\
\text { orang tua ayah dan ibu. Ompung laki- } \\
\text { laki sering disebut ompung halaklahi } \\
\text { sedangkan ompung perempuan disebut } \\
\text { ompung dadaboru atau ompung boru. }\end{array}$ & $\begin{array}{l}\text { Ak } \\
\mathrm{R} \text { menyapa ompung, ompung suhut kepada A dan } \mathrm{B} \\
\text { dan sapaan yang sama } \mathrm{T} \text { kepada } \mathrm{E} \text {; ompung bayo } \\
\text { timbal balik antara } \mathrm{G} \text { dan J, antara I dan L; } \mathrm{R} \\
\text { menyapa ompung boru, ompung dadaboru, ompung } \\
\text { menek, nenek menek kepada B dan sapaan yang sama } \\
\text { T kepada F. } \mathrm{N} \text {, P dan } \mathrm{R} \text { menyapa ompung godang, } \\
\text { ompung halaklahi, nenek godang atau nenek tuan } \\
\text { kepada A dan sapaan yang sama } \mathrm{T} \text { kepada E dan } \\
\text { AA kepada G. CC menyapa ompung mulak kepada }\end{array}$ \\
\hline
\end{tabular}




\begin{tabular}{|c|c|c|}
\hline & & $\begin{array}{l}\text { A dan sapaan yang sama secara timbal balik antara } \\
\text { keturunan pasangan A dan B dan keturunan } \\
\text { pasangan E dan F yaitu keturunan pisang rahut dan } \\
\text { keturunan mora ni mora. Sapaan ompung secara } \\
\text { timbal balik berlaku antara } \mathrm{T} \text { dan } \mathrm{V} \text { kepada } \mathrm{W} \text {, } \\
\text { antara AA kepada } \mathrm{W} \text {. }\end{array}$ \\
\hline 54. & Ompung boru, lihat ompung. & - \\
\hline 55. & Ompung dongan, lihat dongan. & - \\
\hline 56. & Ompung halaklahi, lihat ompung. & - \\
\hline 57. & Ompung mulak, lihat ompung. & - \\
\hline 58. & Ompung suhut, lihat ompung. & - \\
\hline 59. & Pahompu, pahompu adalah сисu. & - \\
\hline 60. & $\begin{array}{l}\text { Pahompu dongan ialah cucu dari ompung } \\
\text { dongan. }\end{array}$ & - \\
\hline 61. & Pahompu mulak, lihat ompung mulak. & - \\
\hline 62. & $\begin{array}{l}\text { Pareban adalah tutur kerabat sesama } \\
\text { laki-laki yang istrinya bersaudara } \\
\text { kandung. }\end{array}$ & 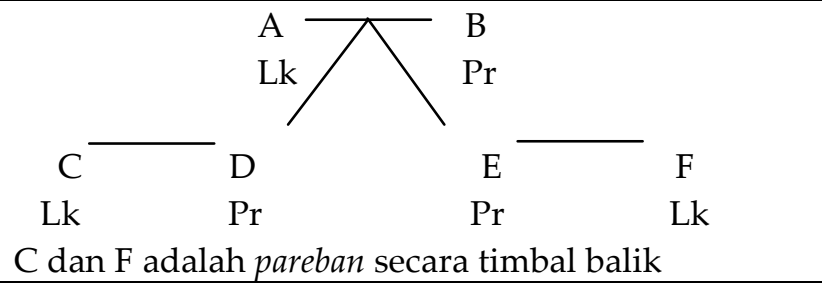 \\
\hline 63. & $\begin{array}{l}\text { Pisang rahut adalah anak boru dari anak } \\
\text { boru. }\end{array}$ & 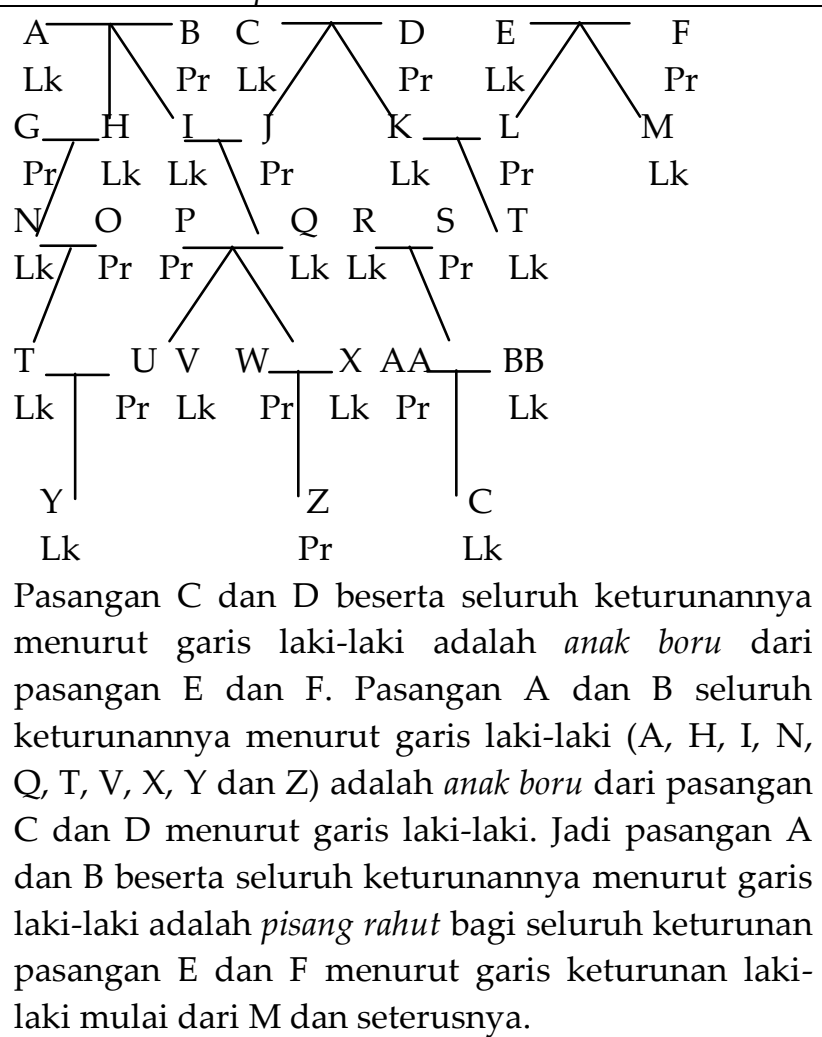 \\
\hline 64. & $\begin{array}{l}\text { Tulang adalah sapaan anak laki-laki dan } \\
\text { perempuan kepada saudara laki-laki } \\
\text { ibu mereka. Sapaan ini juga berlaku } \\
\text { bagi menantu laki-laki kepada mertua } \\
\text { laki-laki. Ada istilah yang sama } \\
\text { maknanya dengan tulang, ialah mamak. } \\
\text { Sapaan ini merupakan adopsi dari }\end{array}$ & 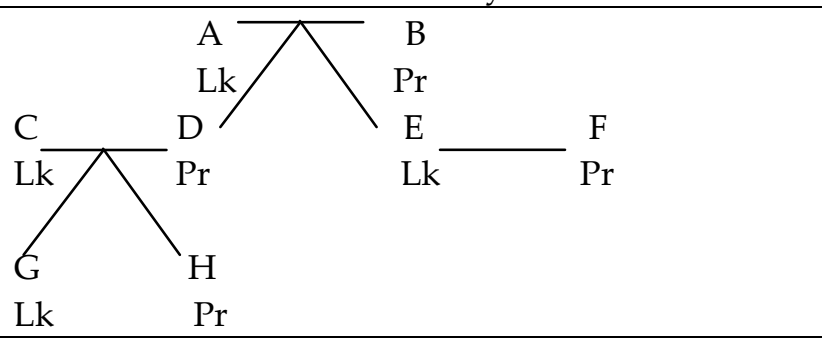 \\
\hline
\end{tabular}




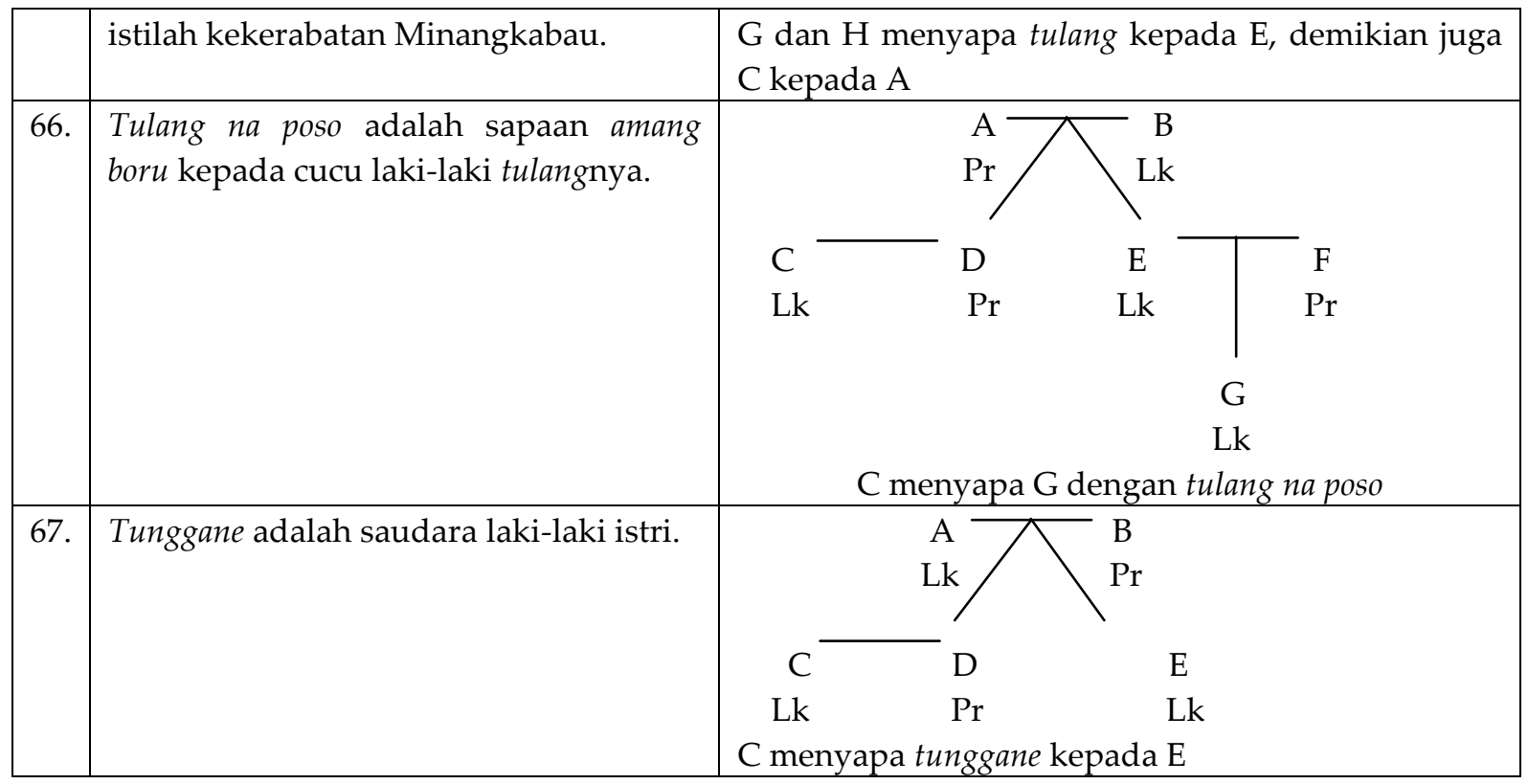

Berdasarkan tabel di atas, maka dapat dilihat bahwa betapa santunnya masyarakat tutur Batak Angkola-Mandailing sehingga partuturon pun dipikirkan secara detil demi menjaga rasa hormat dan sikap menghargai antarkerabat. Bukankah ini juga termasuk interferensi budaya Islam, yaitu saling memanggil dengan sebutan yang baik. Semoga partuturon ini dapat dijaga kelestariannya hingga masa yang akan datang, karena partuturon ini adalah cerminan budaya yang berakhlakul karimah. Di samping itu, dengan memahami partuturon masyarakat Batak Angkola-Mandailing, maka Insya Allah akan memberikan pemahaman siapa saja yang tidak boleh dinikahi tadi karena ada hubungan nasab. Dengan demikian, hal-hal yang tidak baik dapat dihindarkan.

\section{PENUTUP}

Masyarakat tutur Batak Angkola-Mandailing mengenal adanya partuturon yaitu merupakan istilah perkerabatan yang memiliki nilai-nilai luhur adab pergaulan orang per orang dan kelompok per kelompok dalam masyarakat. Tujuan dari partuturon ini, di samping untuk kesantunan juga untuk mengetahui nasab sehingga terhindar dari terjadinya pernikahan sedarah. Namun pada akhir tahun 1960-an dan awal tahun 1970-an telah terjadi perubahan drastis dalam partuturon. Generasi muda sangat malas martarombo, sehingga mereka dengan mudah menerjemahkan kata oom dalam bahasa Belanda menjadi uda. Padahal orang yang disapa $u d a$ itu barangkali adalah tulang 'saudara laki-laki ibu, dalam bahasa Indonesia disebut dengan paman dan dalam bahasa Jawa disebut dengan pakde', amang boru 'suami dari saudara perempuan ayah, dalam bahasa Indonesia disebut dengan bapak mertua atau mertua laki-laki', amang $u d a$ 'adik laki-laki ayah, dalam bahasa Indonesia disebut dengan paman dan dalam bahasa Jawa disebut dengan paklek', amang tua 'abang ayah, dalam bahasa Indonesia disebut dengan paman dan dalam bahasa Jawa disebut 
FITRAH Vol. 01 No.2 Juli-Desember 2015

dengan pakde', apak ketek 'suami dari adik perempuan ibu, dalam bahasa Indonesia disebut dengan paman' atau apak tuo 'suami dari kakak perempuan Ibu, dalam bahasa Indonesia disebut dengan paman'.

Kebiasaan martarombo berkembang dalam pergaulan sehari-hari dengan orang di luar masyarakat Batak Angkola-Mandailing. Mereka mencari tokoh, tempat, kampung, organisasi atau lembaga yang saling mereka kenal dengan baik. Dengan demikian perasaan kebersamaan akan tercipta. Ini merupakan bukti bahwa nilai tutur berperan penting dalam penyesuaian diri dengan lingkungan yang baru.

Menurut Hall, ada 6 karakteristik komunikasi yang bersifat etis, yaitu autheticity, inclusion, confirmation, presentness, spirit of mutual equality dan supportive climate. Berdasarkan tentang cara-cara mengatasi tantangan komunikasi yang bersifat etis tersebut di atas ternyata telah dimiliki oleh masyarakat tutur Batak Angkola-Mandailing juga. Kemacetan komunikasi etika itu dapat diatasi dengan implementasi nilai-nilai luhur budaya masyarakat yang tercermin dalam partuturon atau istilah kekerabatan dalam masyarakat tutur Batak Angkola-Mandailing yang terdiri atas 67 tutur tersebut. Di samping itu, partuturon juga membuktikan bahwa budaya tutur sapa Islam yang santun, terinterferensi pada budaya masyarakat tutur Batak Angkola-Mandailing. 


\section{DAFTAR PUSTAKA}

Alwi, Hasan, Kamus Besar Bahasa Indonesia, Jakarta: Balai Pustaka, 2005

Chaer, Abdul dan Agustina, Leonie, Sosiolinguistik Perkenalan Awal, Jakarta: PT Rineka Cipta, 2004

Harahap, Basyral Hamidi, Siala Sampagul, Bandung: Pustaka, 2004

Syaikh Muhammad, Ensiklopedi Isam Kaffah, Surabaya: Pustaka Yassir, 2012

Yustisiana, Panduan Pranikah For Muslimah, Yogyakarta: Citra Risalah, 2010 